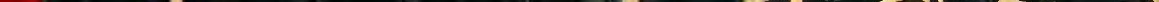




$$
\gamma
$$








\section{UNIVERSITY OF WYOMING.}

Agricultural College Department.

\section{WYOMING EXPERIMENT STATION, LARAMIE, WYOMING.}

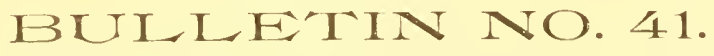

NOVEMBER, 1899.

\section{Some Experiments With Subsoiling. BY B. C. BUFFUM AND W. H. FAIRFIELD.} Station, Laramie, Wyo. 


\section{Wyoming Agricultunal Experimenll Station.}

\section{UNIVERSITY OF WYOMING.}

\section{BOARD OF TRUSTEES.}

Hon. OTTY GRAMM, President, Laramie.................... 1903 GRACE RAYMOND HEBARD, B.S., Ph.D., Secretary, Cheyenne.1903 HENRY L. STEVENS, B. S., M. D., Laramie..................1903 Hon. Timo'THY F. BURKE, LL. B., Vice President, Cheyenne..1901 Hon. JOHN C. DAvis, Treasurer, Rawlins.................. 1901 Hon. NATHAN S. BRISTOL, Casper....................... 1901 Hon. MELVILlE C. BROWN, Laramie...................... 1905 Hon. JOHN A. RINER, Cheyenne.................... 1905 Hon. S. CONANT PARKS, Ph. D., Lander.................... 1905 Hon. THOMAS T. TYNAN, State Supt. Public Instruction. .Ex-Officio President ELMER E. SMILEY, B. A., D. D............. Ex-Officio

\section{MARICLATRII, COMMTTLF OF THE BOARD OF TIUSTEES.}

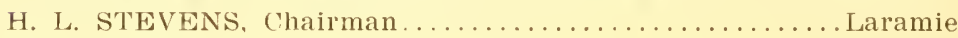

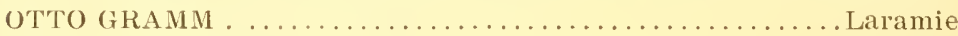

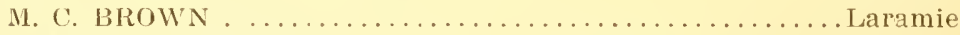

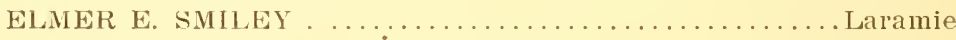

\section{PRISIDENT OF 'THE I MUERSI'Y OF WYOMIM.}

ELMER E. SMILEY, B. A., D. D.

\section{STATION COUNCIL.}

E. E. SMILEY, B. A., D. D . . . . . . . . . . . . . . Director B. C. BUFFUM, M. S., Vice Director, Agriculturist and Horticulturist A. NELSON, M. S., II. A. . . . . . . . . . . . . . . . Botanist E. E. SLOSSON, M. S. . . . . . . . . . . . . . . Chemist

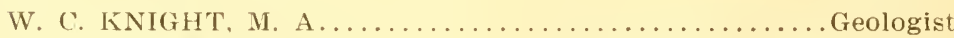

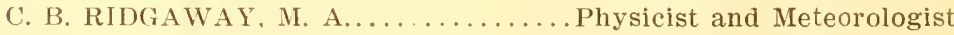
G. R. HEBARD, M. A., Ph. D...................................

W. H. FAIRFIELD, M. S.... Wyoming University Experiment Farm The Horticulturist in Charge,

Wyoming University Experiment Grounds 


\title{
Some Experiments With Subsoiling.
}

\author{
13) B. C. BLFILU AND W. H. FAIRFIEID.
}

The natural reguisites for farming are soil, water, air, luat amd sumshine. With one exception these natmal bless-

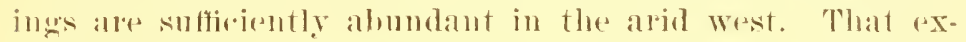
aption is water. The greatest yuestion in our agrioultum is how to make the most of om limited supply of this lifogrivingeresurent. Maling use of our water supply would he a rompalatively simple matter if all the moisture which might lo loromght to the soil rould be lueld there until plants (a) mld make mse of it. lout water is never still. In serking

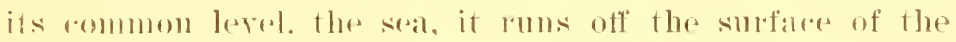

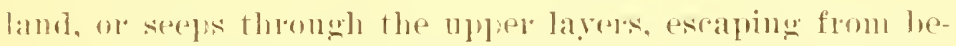
low and that which is retained for a time by the soil is be-

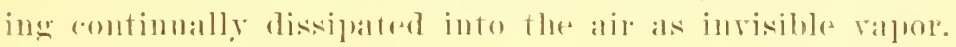

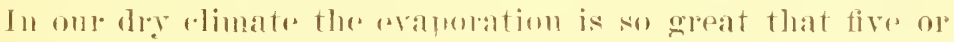

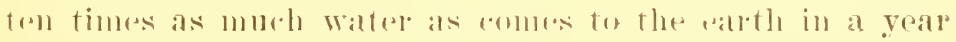

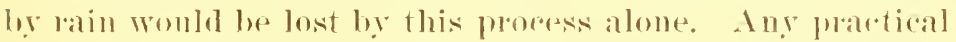
plan then of saviug as moll molstule as gossible for the

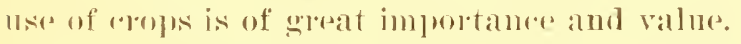

Tillage romsists of stimbing the soil and is as old as agli.

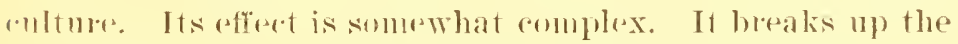

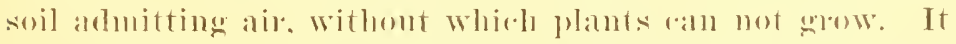
loosems the soil so it beromes suitable for plantime the soed. as woll as fole tlue devielogment of plant loots and for

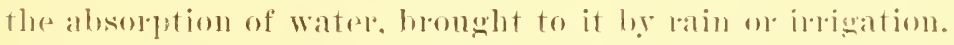
It disintergates lor soil partirles continually mulocking and maling available to the plant new stoles of plant food. It

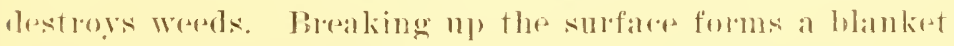
whird prevents the lapid loss of watel hy revalporation. Is it enomele that we shall cultivate the sulefare of the rallth, $\mathrm{ol}^{2}$ 
shall we find it profitable to extend tillage desper into the hitherto undisturbed subsoil?

Snbsoiling is stimging the earth below the region of the plow. For comvenience wr speals of the first eight inches of soil which may be turned over in plowing as the surface soil and all helow this as the subsoil. Plowing turns the surfires soil bottom side up. Subsoiling does not change the prosition of that part of the soil, but it breaks up and stirs the ground below the ordinary depth of plowing. This may be eflected by a spur or prong attached to the plow which breaks up the soil at the bottom of the furrow, or it may be done with a separate implement to be drawn along through the soil beneath the hotem of the furrow after the plow, to stir the ground to greater deptlis than can be deme with a small attachment to the orelinary plow. This implenent is called the subsoil plow and usually consists of a mole or a more or less flat piece of iron pointerl at one end and attached to the beam by a strong flat rertical blade. When drawn through the soil in the bottom of the furrow left by the plow this implement cam be made to break up and stir the subsoil to a depth of from one to two or more fect.

The adrantages claimed for" sulsoiling are that it makes more room for root development, and enables the plant to extract food and moisture from a greater area, and that by loosening up more of the soil its caparity for absorbing and retaining moisture is incrused. By the absorption of greater amounts of moistme in winter and spring it is supposed that subsoiling prevides against summer dronth. It is reasonable to suppesse that this is what would happen and the many favorable reports on subsoiling from humid and semi-arid regions indicate that loosening the lower layers of soil is a raluable way of conserving moisture for those regions. Before discussing the effects of subsoiling in Wyoming the differences between a truly arid region and one 
whirlo is only semi-ald should be brietly pointrd ont. Places where the ammal rainfall is less than fiftera inches ate gen-

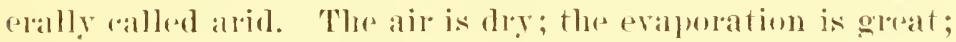
the rainfall is mot suftiredent to matmerentivated erops. In

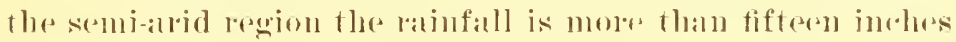
and may le momgle to mature potitable ropos if the moist-

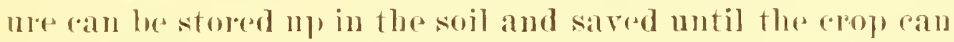
male nse of it. In Wyoming the comditions are touly ard muless it he in the extreme northeastern portion of the state. Theres is little foreipitation during the fall and wintereso

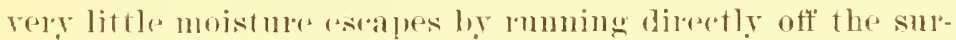
fare of the land. If thru, subsoiling is not necessaly to in-

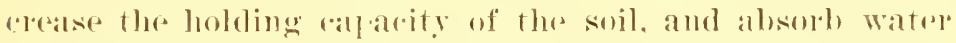
during time of "xtma suply. will it save more of the water which may he applied atifirially during the growing season and will this and other alvantages make it pofitable to go to the "xtrat "xpense of surel tillage in onl state?

To solve this question we have heren experimenting with subsoiling for three years and this hulletin is published to rejort the results obtained. The experimsul was romdurted in the same manner on the serral experiment fallus in the state. Enfortumately the records of the Lander fallom were lost in transit, and the publication of this hullutin has beroll long delayed with the hope they might be fomm. The soil of the Lander and sundance farms is almost identieal. the altitude of the two places is not far different and while the experiment in subsoiling was only earried ont one season at Sumbluce, a comparison of the lesults obtained womld be highly interesting. The rlimate of sundance is semiarid 11 sub-humid, (rojs boing raised withont irrigation, while that of Lander is arid and no reps are latised without irrigation. A comparison of the results at these places would give more trustwolthy evidence of the difference in value of subsoiling under surh remditions of climate and farm practice.

The experiment was hegum in the suring of 1.896 and car- 
ried out that rear at Laramie, Lander, Sheridan, Sundance and Wheitland. In 1897 the copping was repeated on the same land at Latramie. Lamder and sheridan, and in 1s!K, at Laramio only.

\section{PLAN OF THE EXPERIMENT.}

Following is an outline of the instructions for subsoiling which, witls slight modifications for ach locality, wre furnished the farm superintendents in the spring of 1896 -

This experiment is to be arried on alike on each of the farms. Seleret a suitable acre plat. l'low the land orep the whole plat the same and let all other opreations surh as hatrowing, ote., he the same fol all parts of the plat. Subsoil thoromghly one-half of the plat. Mark calefully and permanently the line where the sulsoiling stops.

Divite the plat into four equal parts so one-hilf of each fomth is on the sulsoiled portion and one-half on the part

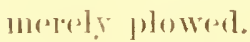

Foun the first fometle acres plant bats.

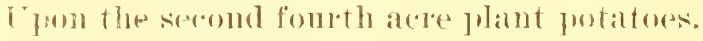

lyou the thied fometh acere plant wheat.

bivide the last fomelh into two jalets and plant beets on the one and and on the other.

Treat the arops on the plowed and subsoiled band the

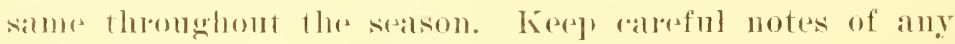
variations on the two parts of each platt.

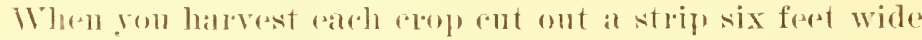
along the line on which the subsoiling stopse alsting out

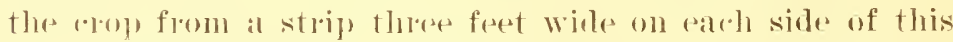

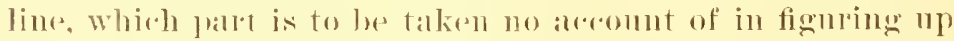
the yields on subsoiled land or lamd not subsoiled. This is important as the refterts on the ground treated or untreated will bearle aleress the line some distance.

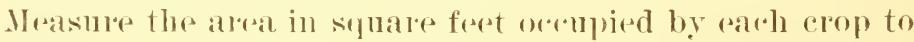
bo used in figming ul the rields. In the a ase of rowed 
crops, allow for the number of rows at their distance apart and take the length of row on treated and untreated land.

This experiment will be repeated mpon the same ground for a number of rears to determine the effect of subsoiling on soil and erops-.

In 1sen some additional land was subsoiled and on one plat of oats covering one-half acre an accurate measurement was male of the irrigation water used. In 1897, the next ral" aftel the land was sulsoiled for this experiment, the I'loysirist made a study of the moisture content of different soils whirh was puhlished in Bulletin No. 35 of this Station, a. restume of which is nset in this report.

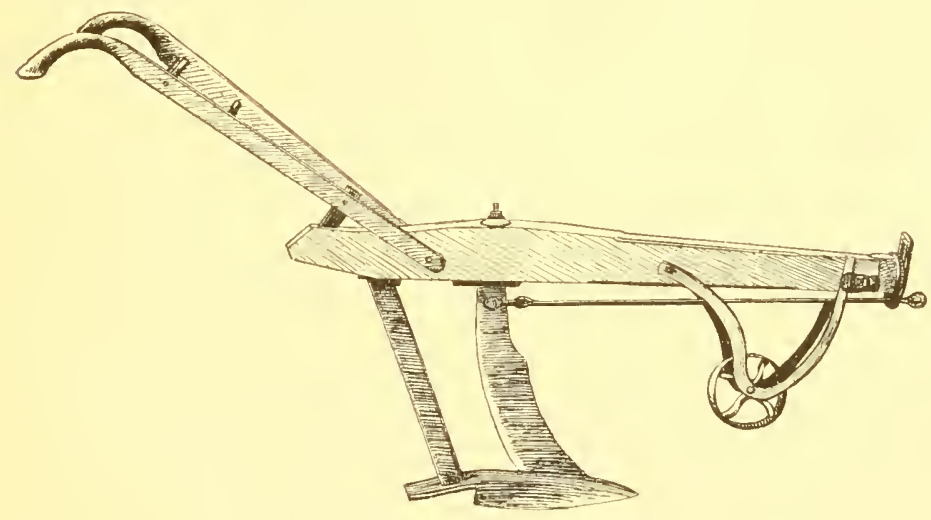

\section{Results of the Experiments.}

l'lants of different kinds art very differently when grown on subsoiled land. 'The efferet on a cropl of loosening the soil to a depth greater than by ordinary plowing is also very different on different soils and under varying climatic conditions. Onr experiments were carried ont in widely separated parts of Wroming and with the more important crops raised in each section. Again there are often accidental variations which throw doubt on the value of an experiment and where possible the work has been repeated more 
than one season. The conchusions reached have been carefully drawn and we believe the results of these experiments are worthy of cousideration by our farmers.

The soil on the station farm at Laramie contains considerable gypsum and lime carlonate, is quite sticky when wet and hecomes firmly rompacted below the plow. The land sulected for this experiment had been cultivated for a number of rears. It was plowed about eight inches deep and one-half the plat was subsoiled to a deptlo of fourteen to sixteen inches in 1 pril, 1896. The ground was so hard that four horses were required to pull the subsoil plow and if harger areas were to be treated six horses would be necessary. The land was not again subsoiled but the differener in the vield of crops produced was observed for three seasons. This shows the lasting efferts of subsoiling and the return which may be expected from one such treatnent, and throws light on the absorption and retension of water through the entire year. The second year there was a slight difference in the depth of the plowing on the two portions of the plat. Where the lant had been subsoiled the plow sunk one to three inches deeper than on the plow d portion.

On the other station farms in the state the plowing and subsoiling was done in the sane manner as at Laramie. At Sherdan the soil is clay underlaid with true hardpan. It is not known to what extent this hardjan was broken up by the subsoil plow. At Wheatland the soil conditions are much the samr as those at Laramie. At Sundance the soil is deep contains gypsum and murh of the subsoil consists of red shale which is not tenaceous but comparatively easy to work.

The average rainfall is nearly ten inches at Laramie; about the same at Wheatland, nearly fourteen inches at Sheridan and twenty inches at Sundance. At Laramie and Wheatland from fifty to sixty percent of the total annual precipitation falls in the growing montlss of May. June, 
July and Angust. The greater amount of precipitation at sundance and the fact that the land was not irrigated undoubtedly acounts for some of the difference noted in the efrects of subsoiling between the sundance and other farms.

\section{Subsoiling for Grain Crops.}

Table I. gives the effects of subsoiling on the yields of wheat. Thongh the difference was not great, the yiold from the subsoiled land was less than that from the land only phowed, at Lammie, the rear the subsoiling was done. The second and third yoas there was a slight increase in yield from the subsoiled land. The increase in the yield of straw is greater in proportion than that of grain. This condition would be expected as the increased feeding area of the roots and other conditions faroring rank growth would produce more straw and less grain where the growing season is short. The reason for this is indicated in Wyoming Station Bulletin No. 87 on the "Stooling of Grains." It is a general law that under adverse conditions plants strive to mature seed in order to reproduce themselvos. Cnder these conditions then, grain will matme earlier and produre moresed in proportion to the rest of the plant than where ererything is favorable to long continued growth.

TABLE I. - Subsoiling for theat.

Yields in Pounds per Acre.

\begin{tabular}{|c|c|c|c|c|c|c|c|}
\hline & & \multicolumn{2}{|c|}{ LARAMIE. } & \multirow{2}{*}{$\begin{array}{c}\text { SHERI- } \\
\text { DAN. } \\
\text { Grain. }\end{array}$} & \multirow{2}{*}{$\begin{array}{c}\text { WHEAT- } \\
\text { LAND. } \\
\text { Grain. }\end{array}$} & \multicolumn{2}{|c|}{ SINDANCE. } \\
\hline & & $\begin{array}{l}\text { Straw } \\
\text { and } \\
\text { Grain }\end{array}$ & Grain & & & $\begin{array}{l}\text { Straw } \\
\text { and } \\
\text { Grain. }\end{array}$ & Grain. \\
\hline \multirow{2}{*}{ First Year. } & \multirow{2}{*}{$\begin{array}{l}\text { Subsoiled. . . . . . . . . } \\
\text { l'lowed. } \\
\text { Gain. . . . }\end{array}$} & $\begin{array}{l}362 i \\
2 \times(i) 3\end{array}$ & $\begin{array}{l}943 \\
997 \\
\end{array}$ & $\begin{array}{l}3000 \\
2550\end{array}$ & $\begin{array}{l}1: 306 \\
\text { Jiliti }\end{array}$ & $\begin{array}{l}34+20 \\
3441\end{array}$ & $\begin{array}{l}1440 \\
11+60\end{array}$ \\
\hline & & 236 & 54 & 450 & 112 & $4 \times 0$ & 280 \\
\hline \multirow{2}{*}{$\begin{array}{l}\text { Second } \\
\text { Year. } \\
\end{array}$} & 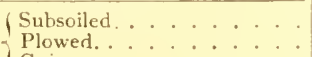 & $\begin{array}{l}? 174 \\
1 \times 94\end{array}$ & $\begin{array}{l}901 \\
876\end{array}$ & $\begin{array}{l}27100 \\
1950\end{array}$ & & \multirow{3}{*}{$=$} & \\
\hline & IGain. . . . . . . & 280 & 25 & 750 & & & \\
\hline \multirow{2}{*}{$\begin{array}{l}\text { Third } \\
\text { Year. }\end{array}$} & $\left\{\begin{array}{l}\text { Subsoiled........ } \\
\text { Plowed. . . . . . }\end{array}\right.$ & $\begin{array}{l}21 \% 0 \\
2128\end{array}$ & $\begin{array}{r}308 \\
-333 \\
\end{array}$ & & & & \\
\hline & IGain.... . . . . . & $4 i 3$ & 85 & & & & \\
\hline
\end{tabular}


The increase in rield of wheat at Laramie the second and third rears on the land which had been subsoiled is but little morr than enough to halance the decrease the first season. It slueridan there was an increase in vield the first rear of seren and one-half bushels and the second year of twelve and one-lanlf bushels on subsoiled land. At Wheatland and sinndance the increase on subsoiled land was small but was over twice as much at sundance as at Wheatland.

The results with oats are giren in Table II. The lengthening of the season for oats hy subsoiling was more marlied than with wheat. At sundance the oats on the sulssoiled portion of the plat seemed to be making better growth during the first part of the season but, when harvested. Superintendent Hoyt reported a smaller vield than was obtained frem the land terated in the ordinary way. At laramie the bats were later in reaching maturity on the subsoiled land. It may be stated that late varieties of nearly all crops, if not interferes with by frost, produre heavier yields than those which reyule only a short season in which to maltnre. Lengthening the growing season for the same rariety would be expected to increase the yirld, but at the high altitude of the liund ores a large part of $W^{t}$ roming the time betweren late and early frosts is comparatively short and alliness in ripening is a most important factor. There wats a slight incruase in yield of oats the first two years, but the third scasom the dererease in cropl was almost enough to balance the gains of the first two seasons, though whether or not the efferet the third suson was due to subsoiling may be questioned.

At sheridan there was a loss of serenty ponnds more of oats the first year than was gained the second year by subsoiling. It Wheatland there was a small increase on the subsoiled land, but the variation was small, probable not more than would be obtained on ans two plats, though treatod exactly alike. To all appearances the rields of oats 
Were not matterially influenced at any place by subsoiling the land.

TABLE II.-Subsoiling for Oats.

Yield in Pounds per Acre.

\begin{tabular}{l}
\hline \hline \\
\hline
\end{tabular}

bratuse of the high altitude with the accompanying short seatsons and rold nights, (.01\%ll is not grown at Lallatmis, sol ballery was planted on one pertion of the sulsoiled plat at this plater and rorn was growere at sheridan, Whratland and simdance instead of balley. The results with haley and roln ale given in Table III. 11 is doubtful if any efferet on the violds of barley one was or another wan be traesd to the snbsoiling. The first year there was less straw and mores watin on the subsoiled lanel. The seromel reatr this was reveresed, there being more straw and less grain where subsoiled, and the third year there was alowimately no diffremes in the podurtion of straw, but there was quite a derease in the viesd of grain.

subsoiline for corm did not paye at the sub-statioms ex"(p) at sundances where a good increase in viold was obtained. It shelidalu there was quite a lalge derease in rield of roln the first season, and no difference the second year. supreintentent Lewis reported that the corn dir not mature as well on the subsoiled land. The first year the estimated rield on the subsoiled part of the plat was 
thirty bushels per aere, and on the land not subsoiled thirtyfive bushels per acre. Ten per cent. of the corn on the land merely plowed rijened thoroughly, while all the grain from the subsoiled portion of the plat was soft and immature. The serond season fifty bushels of mature and thirty bushels of soft gratin per arre were hallested from each portion of the plat. To compare with others in the table, these yields have been reduced to pounds by using the wright of serenty pounds per bushel for corn in the ear.

At Wheatland during the season of 1896 , the supply of water for irrigation was somewhat limited, and if the crops suffered for water. as they probably did to some extent, these on the subsoiled land would be expected to have the advantage. Mr. M. R. Johnson, the superintendent, states that all the rops mate a better growth on the subsoiled land, that they seemed to withstand drouth better, and that the quality as well as the quantity of the product, indicated beneticial refrects from subsoiling. The corn gave an increased yield of :26:8 pounds prer acre on the subsoiled land.

TABLE III._Subsolling for Barley and Corn.

Vield in Pounds per Acre.

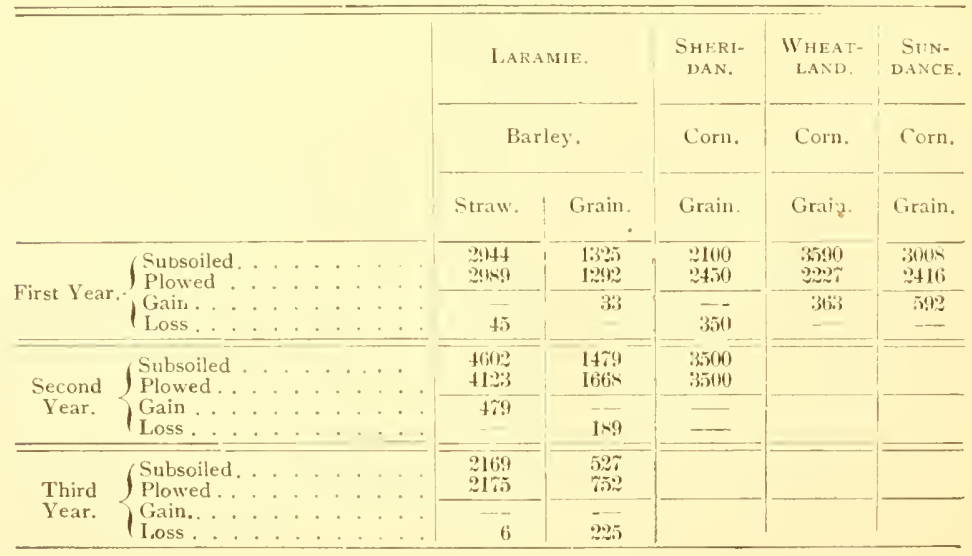




\section{Subsoiling for Root Crops.}

The fact that deep soils are favorable for the growth of roots is recognized everwhere, and as would be expected subsoiling produced more marked effects on the vields of root crops than it did on grains. In Table IV., reporting the lesults with loot crops, it will be seen that in every trial there was increased rield from the subsoiled land, and in some instanes there are important gains. The lasting meret of subsoling is well brought ont in this table. All the tables show that, al shermall, where the experiment was arliof ont two yatrs, and at Laramie where results were olotained three seasons, the beneficial effect of subsoiling is weatry the seront year than it is the season the subsoiling is dome. This indicates that it would be advisable to subsoil in the fall rather than in the spring. The third year the soil has probibly become compacted again so the effeet is much less than it is the first two seasons.

TABLE IV.- Subsoiling for Root Crops.

Yield in Pounds per Acre.

\begin{tabular}{|c|c|c|c|c|c|c|c|c|c|}
\hline & \multicolumn{3}{|c|}{ LARAMIE. } & \multicolumn{2}{|c|}{ SHERIDAN. } & \multicolumn{2}{|c|}{$\begin{array}{l}\text { WHEAT- } \\
\text { LAND. }\end{array}$} & \multicolumn{2}{|c|}{ SUNDANCE. } \\
\hline & 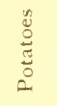 & $\frac{\infty}{2}$ & $\stackrel{\varrho}{\Xi}$ & 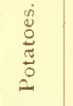 & صั & $\begin{array}{l}\stackrel{0}{0} \\
\frac{0}{0} \\
2\end{array}$ & $\stackrel{\infty}{\mathscr{U}}$ & 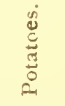 & 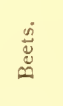 \\
\hline \multirow{2}{*}{ First Jear. $\left\{\begin{array}{l}\text { Subsoiled.... } \\
\text { Plowed . . . . . } \\
\text { Gain . . . }\end{array}\right.$} & & & $\begin{array}{l}x+165 \\
\times 3 \times 10\end{array}$ & $\begin{array}{l}125 i x \\
10600\end{array}$ & $\begin{array}{l}13 \times 60 \\
126001\end{array}$ & $\begin{array}{l}2425 \\
2151\end{array}$ & $\begin{array}{l}8 \%(0) \\
\times 0(0 !)\end{array}$ & $\begin{array}{l}5224 \\
69460 \\
\end{array}$ & $\begin{array}{l}17161 \\
14+41 \\
\end{array}$ \\
\hline & & & 315 & $20: 34$ & 1260 & $2 \pi t$ & 243 & 126 it & 2320 \\
\hline \multirow{2}{*}{$\begin{array}{l}\text { Second } \\
\text { Year. }\end{array}$} & $\begin{array}{l}367 \% 2 \\
2620\end{array}$ & $\begin{array}{l}13 \times 933 \\
11(443)\end{array}$ & & & $\begin{array}{l}24 \pi 00 \\
24 \pi ! 5\end{array}$ & & & & \\
\hline & $105: 2$ & 1250 & & & 3905 & & & & \\
\hline \multirow{2}{*}{$\begin{array}{l}\text { Third } \\
\text { Year. } \\
\text { Plowed. } \\
\end{array}$} & $\begin{array}{l}69+0 \\
6 \times 6.5 \\
\end{array}$ & $\begin{array}{l}54.50 \\
4522\end{array}$ & & & & & & & \\
\hline & 75 & $92-1$ & & & & & & & \\
\hline
\end{tabular}

POTATOES-At Laramie the potatoes planted the first rear failed to grow because the soil was too dry. The second and third years the stand was poor and small yields were obtained, but there was a good increase of crop on the sub- 
soiled land. In Table IV. only the yields of potatoes which were of sufficient size for market are reported. The proportion of large and small tubers on the two kinds of ground and the increase in size on the subsoiled land is of interest. Table V. wives the vields of larese and small potatoes. the perent malkotable and the wright of the largest twelve tubers from rach portion of the plat at Laramie in 1897

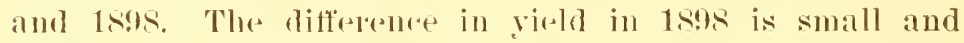
there was practically no differenes in the size of the potators. indicating that little cefeet on this (pop) was produced by the lowe soil having heen loosened up three rears before. The serond seison after stuboiling. howerer, there was not only a latrow increases in the yield, but in the size of the tuluers as well.

Table V.-Effect of Subsoiling on Size of Pofutoes.

at Laramie, $W_{\text {yo. }}$

\begin{tabular}{|c|c|c|c|c|c|c|c|c|}
\hline & \multicolumn{4}{|c|}{$1 \times 9 \%$} & \multicolumn{4}{|c|}{ Is!s: } \\
\hline & \multicolumn{2}{|c|}{ Vield. } & \multirow{2}{*}{$\begin{array}{l}\text { Percent } \\
\text { llarket- } \\
\text { able }\end{array}$} & \multirow{2}{*}{$\begin{array}{l}\text { Weight } \\
\text { of } \\
\text { largest } \\
\text { twelve. }\end{array}$} & \multicolumn{2}{|c|}{ Vield } & \multirow{2}{*}{$\begin{array}{l}\text { Percent. } \\
\text { markiet- } \\
\text { abie. }\end{array}$} & \multirow{2}{*}{$\begin{array}{l}\text { Weight } \\
\text { of } \\
\text { largest } \\
\text { twelve. }\end{array}$} \\
\hline & Large. & Small. & & & Large, & Small. & & \\
\hline $\begin{array}{l}\text { Subsoiled } \\
\text { Plowed. }\end{array}$ & 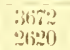 & $\begin{array}{l}1.52 \\
16 i 60\end{array}$ & (6). & 51 & $\begin{array}{l}6 ! 40) \\
(1 \times 6) 5\end{array}$ & $\begin{array}{l}3+17 \\
2012\end{array}$ & i⿱亠䒑十. & $\begin{array}{l}+6 i \\
+6\end{array}$ \\
\hline Gain. & 1052 & $x, 0$ & 4.1 & 0.6 & $\pi$ & 30.5 & & \\
\hline
\end{tabular}

At Wheatland thes sulsobiling perduese litte effect on potatoes. The increase in rield of marketahle potatoes was

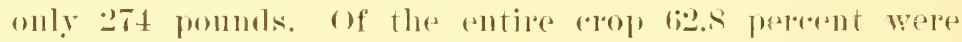
malletable on subsoiled land, and on the land not sub-

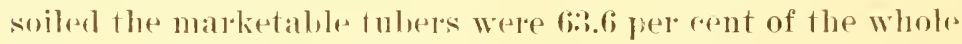
(rop). It Sheridan and sumdanes the small potatoes wepes not reported, but at sheridall the ladrest 12 tubers from subsoiled land weighed six and one-half pounds and from plowed land six pounds.

SlOA R REETR-Lubsoiling gave satisfactory increase in yields of sugar loeets at ereery planexeept sheridan. It 
Laramie the increase in size of the beets is worthy of special mention. Not only were the largest twelve very different, from the two plats, but the average size of the roots was murh larerer on the deep soil. In 1897 the largest twelve roots from the sulsoiled plat weighed nineteren pounds and from the plat not subsoiled twelve roots woighed eleven pounds. In 1898 the difference was less.

Twelve of the largest beets from the subsoiled plat woighed in the agerresate seven and one-half pounds and foum the plowed land six and one-laalf pomuds. Analysis of the berets showed slightly hetter besults from the land not sulsovited. liests from subsoiled land routained 19.7

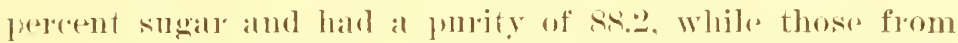
the adjoining plowed land containes ?0.3 pereent sugar

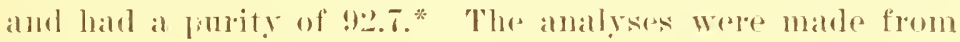
the reop of $18: \%$, the serome reale after subsoiling.

\section{SUBSOILING, IRRIGATION AND SOIL MOISTURE.}

The subsol plats were small, and als it was meersaty to treat the (ropes alike on bolh parts of the plat, it was im-

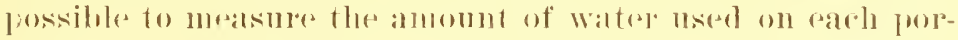
tiens. An "xperiment was allerel ont with different amounts of water on the petators growing on the subsoiled

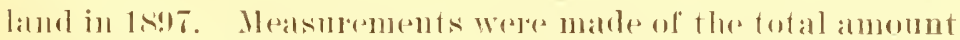
of water used on the blat, one lialf of which was sulsoiled alme also on another subsolad plat, and we alle able to romgater these measmerements with the amount of water used

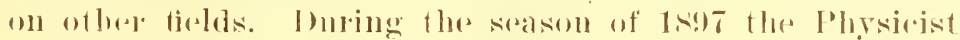
made a serites of moisture determinations on the differest soils and publisled the lesults in bulletin No. :5.) a resume of whirls is shown in the areomplanying diaglan. Theses

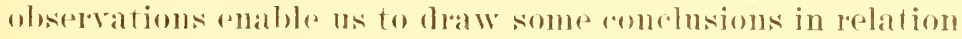
to the soil moistne and the use of irrigation water on surels dereply tilled soils at latamion.

In 1s!tf the batley, oats and wheat, were irrigated twire. 
on the acre of land one-half of which was subsoiled. At the first irrigation on July 2, enough water was applied to cover the land 11.4 inches deep and at the second irrigation enough water was applied to cover the land 6.12 inches deep, or a total depth for these crops of 17.52 inches. The precipitation for the year was 10.75 inches of which 4.75 inches fell during the months of May.June, July and August. This gare a total of 22.27 inches for the growing season or 2s.2. inches of water for the year. The same year wheat and bats on other fields received enough water by irrigation to cover the land to a depth of 14.88 inches, and barley recesired 1.5. inches of water, showing that enough more water was applied to the acre, one-half of which was subsoiled, to corer the whole plat three inches deep. If thim was due to the effect of subsoiling it means a requirement of six inches more water on the subsoiled land. Infortunately the recold of measurements of water on the subsoiled plat was broken, so it cannot be reported for 1897 , but in 1898, trustworthy measurements were secured. The wheat, oats and harley were irrigated twice. On June 24, enough water was applied to cover the land 11.52 inches deep, and July 13 enough water to cover it 9.12 inches deep or a total of 20.64 inclus. Inchuding the rainfall, the land received enough water during the growing season to cover it to a depth of 25.22 inches, and in the yeal 28.26 inches. It is not possible to draw conclusions in regard to the rffect of the subsoiling on this plat in 1s9s, as other crops of the same kind received rarying quantities of water, some more and some less than this amount.

On another plat, howerer, which was subsoiled in the spring of 1898 and planted to oats, the amount of water used in irrigation was very large. The land was imigated twice. At the first irrigation on .June 27, enough water was used to cover the land 30.S4 inches deep, and all of it was absorbed by the soil. It the second irrigation, July 11, enough was used to corer the land 1:3.4t inches deep, 



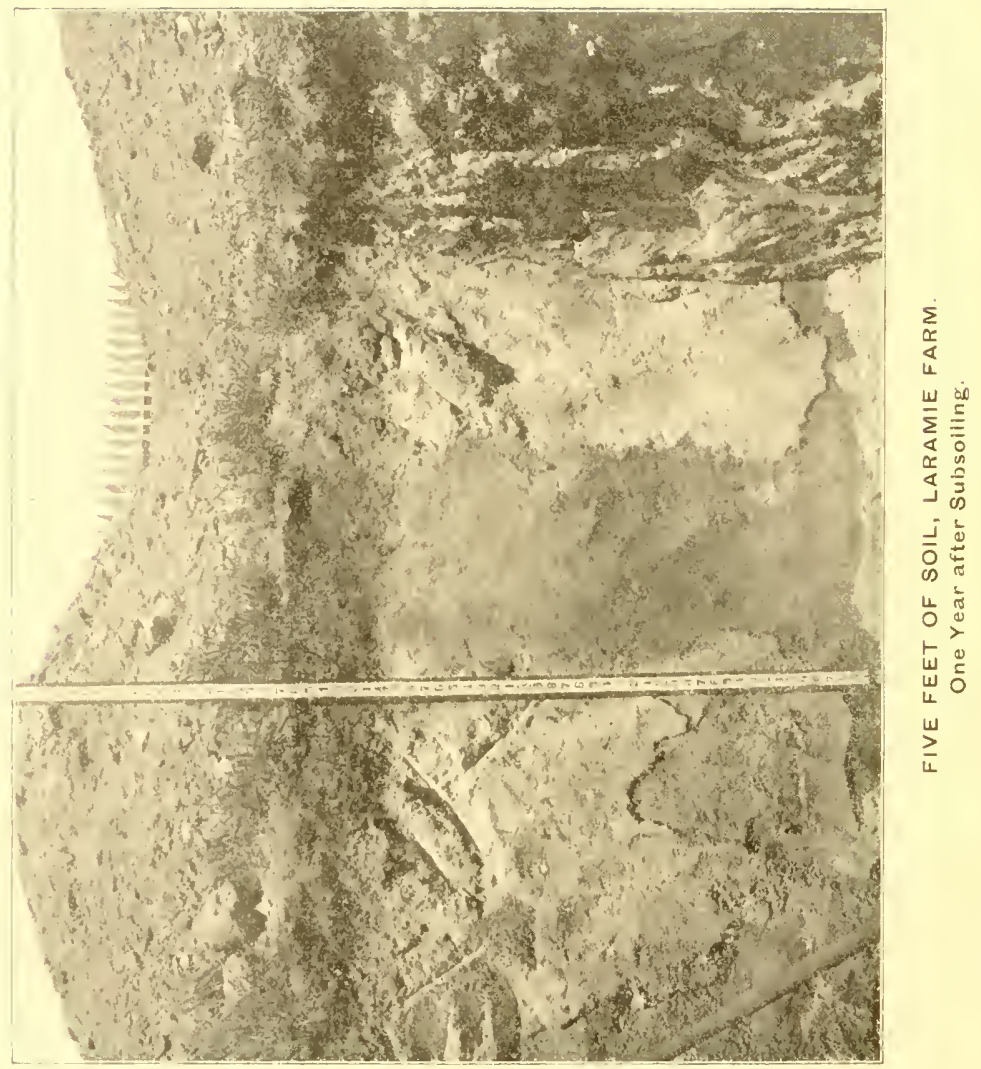


making a total for the season of 44.48 inches, or 3.69 feet. Includiug the rainfall, this gave a depth of water brought to this land in the ytar of 51.91 inches or for the growing suason of 48.47 inches. The amounts of water used on other

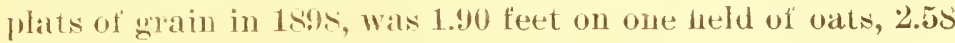
feet tor oats on sod, 1.55 feet for oats and cultivated grain, 2.70 feet for one plat of barley, $1.7 \pm$ feet for one plat of wheat and oats, and : $:(6:)$ feet for one field of wheat, which was irrigated three tiures and given an unusual amount of water.

The illustration of five feet of soil on the Experiment Sta tion is made from a photograph taken one year after the subsoiling was done. The upler eight inches of dark soil is the portion turned orer each year by the plow. The next six or eight inclues of subsoil shows the effect of having been loosened by the subsoil plow, leaving it porus. On the native plains the soil below the first one or two feet may not have been wet for ages, as the natural rainfall is not suticient to wet more than the first few inches of surface, and there is practically no difference in composition between the surface and subsoil. Breaking up the layer which is compacted by the plow in the bottom of the furrow gives the water a new reservoir below the plowed land and affords a means of escape by serebage, which would account for the large amounts neeessary to soak it up when irrigated and perhaps also for easy dissmmmination and loss of the moisture afterwarks.

In 1898 the potatoes on the plat, one-half of which was subsoiled, were divided into two parts. One part was irrigated twice, using only a small amount of water each time and the ofher part was irrigated three times. Those irrigated twice reserived enough water to cover the land 2.04 inches deep ou . Tuly 2S, and 1.56 inches deep on August 4. The ons irrigated threr times received the first irrigation on .July 7 , when enough was applied to cover the land 10.20 inches deep). At the other two irrigations they were 
given the same amounts as the potatoes which were irrigated but twice. The results are given in Table VI., which shows the amount of water applied and the rields on land subsoiled and not subsoiled.

Taple VI.-Potatoes with Tivo and Three Irrigations on Subsoiled Land. Laramie, Wyo., 1898.

\begin{tabular}{|c|c|c|c|c|c|c|}
\hline - & $\begin{array}{c}\text { Total } \\
\text { amount of } \\
\text { water } \\
\text { applied. } \\
\text { lnches. }\end{array}$ & $\begin{array}{l}\text { Yield on } \\
\text { land } \\
\text { plowed } \\
\text { ' 'ounds. }\end{array}$ & $\begin{array}{l}\text { Yield on } \\
\text { subsoiled } \\
\text { land. } \\
\text { Pounds. }\end{array}$ & $\begin{array}{l}\text { Average } \\
\text { yield. } \\
\text { Pounds. }\end{array}$ & $\begin{array}{l}\text { Weight o } \\
\text { largest } \\
\text { twelve } \\
\text { plowed. } \\
\text { Pounds. }\end{array}$ & $\begin{array}{l}\text { f Weight of } \\
\text { largest } \\
\text { twelve } \\
\text { Subsoiled. } \\
\text { Pounds. }\end{array}$ \\
\hline $\begin{array}{l}\text { Irrigated twice } \\
\text { Irrigated three times. }\end{array}$ & $\begin{array}{r}3.6 \\
13.6\end{array}$ & $\begin{array}{l}4920 \\
-6.54\end{array}$ & $\begin{array}{l}5290 \\
5.991\end{array}$ & $\begin{array}{l}5131 \\
8675\end{array}$ & $\begin{array}{l}3.6 \\
5.6\end{array}$ & $\begin{array}{l}3.9 \\
5.3\end{array}$ \\
\hline Increase . . . . . . . & 10.2 & $3 i n i$ & 3301 & 25,44 & 20 & 1.4 \\
\hline
\end{tabular}

This shows an increase due to the increased amount of water applied, of over serenty-six pereent on plowed land, and sixty-two frerent on subsoiled land, the average inrease being about sixty-nine pere ant. The fact that inrrased water applied in irrigation did not increase the (\%) as mull on subsoiled land as on the land which was plowed is in favor of the subsoiled lanel as it indicates that the coop actually needed less watere to produce the same virld. This may he true, as the variation is small and may be accidental, and it is possible and probahle that more water was artually absorloed by the subsoiled portion when irriwated. It is mufortunate that we are not able to make a like comparison the first and serond seasons after subsoiling.

If moisture comes to the soil during any part of the rear, the friends of subsoiling clain that it is retained and made more avalable to the "rop. The study of the moisture in the soil of the different plats at Laramie in 1897, which was made by the Department of Physics, does not seem to bear out such statement. The acomlanying chart illustrates the difference in moisture content of the soils on sod land, on land which was plowed in the usual way and on the subsoiled land. The determinations of moisture were made 
daily and these have besm areraged for earlo month. The

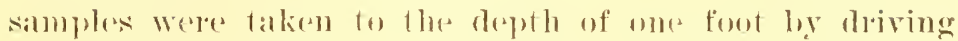
tubes about one inch in dianmetere into the soil. On the loose glound some at the soil misht be driven down in front of tler tube instrad wi anterime it, but the samples were

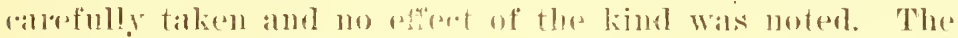

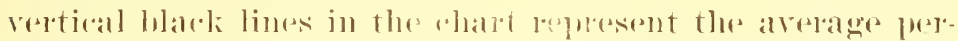

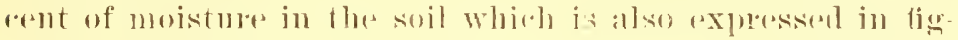

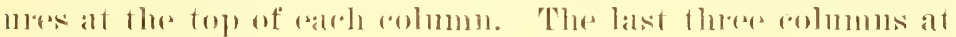

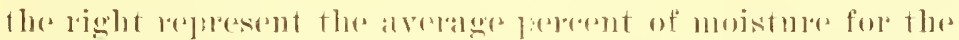

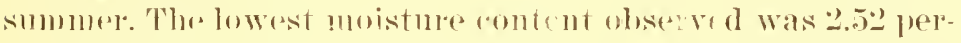

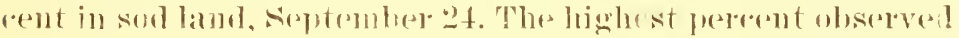
was 2.2.:5 on the lausl plowed but not subsoilod and

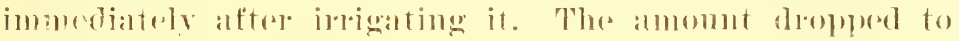

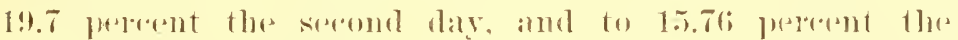

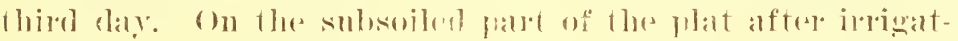

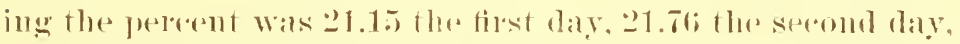

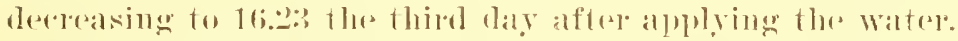

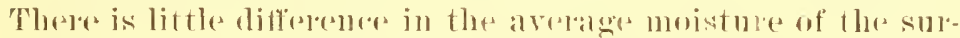
fares soil on the plowed lambl and that subsolled, hut what

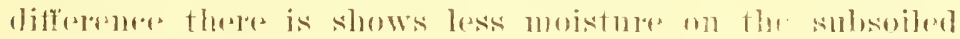

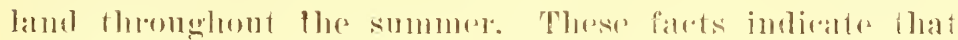

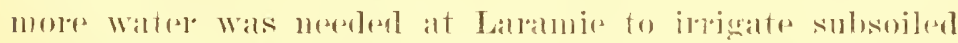

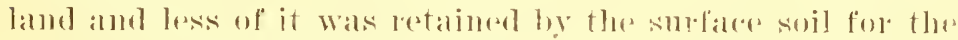
nse of the plants genwing thereon. It is gussible there was mole water in the soil helow the deptle of these salmples om

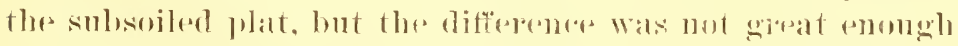

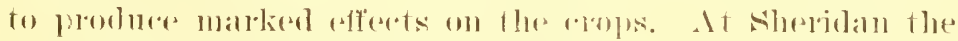

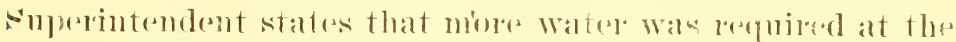

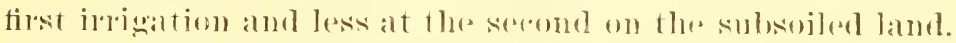

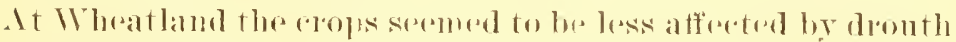

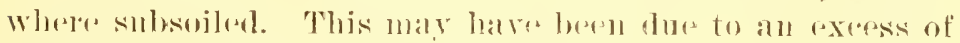

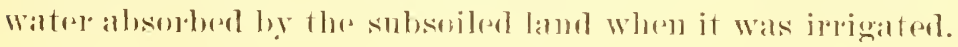




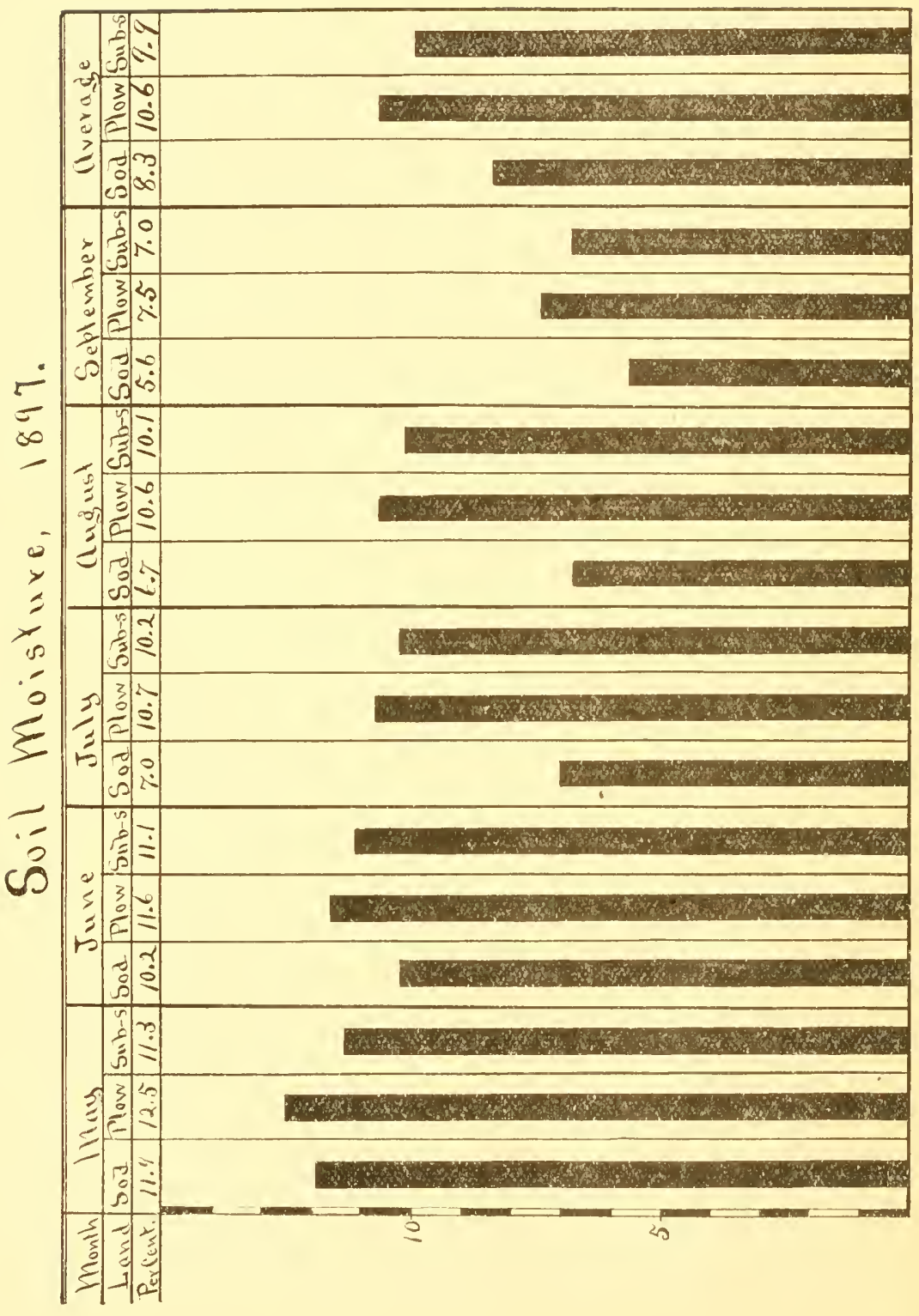




\section{DOES SUBSOILING PAY?}

The test of the advisahility of any operation on the farm lies in the final result measured in dollars and cents. Subsoiling is an expensive operation which mope than doubles the ordinary rost of preparing the land for the crop by plowing. The rost of subsoiling will vary with the condition of the soil and the price of labor. The cheapest it could be done on large areas, and thoroughy done as in these rXjeriments, womld lee at at rost of not less than three dollask pere acer. Whore we broke up the subseil to a depth of fonrteen to sixteen inches. on small plats the expense was five or six dollaws per are. Inloss it increases the vield, improves the puality and themefore the value of the rop. or reduces the expense of produring it, or requires less water so the same smpply will irrigate more land, the practice of subsoiling ramot he recommended as one to br adopted on the farm.

Referring to Table I. in which the vields of wheat on subswiled land and on land prepared in the ordinary way are compared, it is ovident that the acommulated increase for thres salsons at Lallamie womld not pay tlee expense of one sulsoiling. At sheridan the inceresese of 4.50 pounds of wheat pore are the fiest yeal and 7.s0 pounds the second dee to subsoiling would give a total value of twelve dollars ger ace more from the subsoiled land. If the subsoiling anst fom dollars per acre mowe than the ordinary expense of plowing, the margin of wotit is larege enough. Even though we allow for a romsidelable increase in vields the

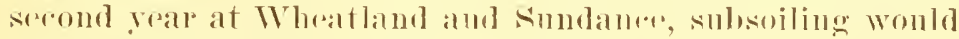
not pay lou wheat in these lowalities.

The results with oats as givere in Table ll. do not show

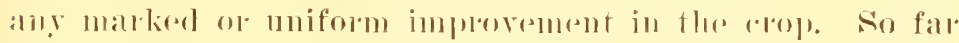

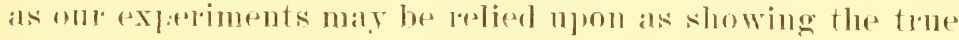
efferts of subsoiling in this state, the indirations are that it will not pas to so prepare the soil for oats. The same 
statement may he made for harley and corn nnless it be at sundance, where the increase the first year and the probability that there womld also be a like incease in the crope the serend rear, indirate that subsoiling for coln might pay in that region.

sulsoiling for root arops did not give a return the first year at Wheatland, harge enough to pay the cost, though the guality of the eropl was improved and the incerease the serond season might leatre a profit. At laramie the increase in the potato clop the second reall (swe Table IV. page 11 , would be werth $\$ 10.50$ to $\$ 13.00$ at the local mar. list priere. On the sleridan farm the inclealsed vield of potatoes the first rear was worth from $\$ 11$ to $\$ 20$, and at sundane form $\$$ to to $\$ 12$. depending on the market price. The value of sugal beets for storek food would make the incleased rields form subseileel land at Lalannir. Sheridan and sundance profitable. As a rule wa belirve that subsoiling for root crops will bring a protitable return.

Whether ol not subsoiling will pay depends lalgedy on local conditions and the kind of renp. Before adopting st) expensive a system of tillage the farmere shomblestisfy him-

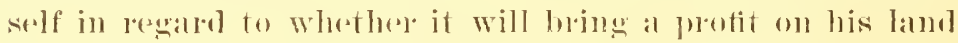
by making small trials. Onf results rall not be said to inditate that sulsoiling in legions which depend on iprigation will materially assist in saving the moistme or make irrigation less neeressary. It is troe that subsoiling ap. parently mitimated the cofferets of drought somewhat in Wheatland, thomgh the increase in the value of the apep was not sufficient to pay for the expense incmered. It is possible that, where water for irrigation is searee, and other. renditions are faverable, subsoiling might make the water

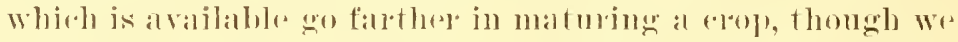
have besen mahle to prove any valuable saving of moisture where the sulsoil is madr porms. 


\section{SUMMARY.}

The expense of subsoiling to depths of sixtren or eighteen inches is from three to six dollars per acre.

subsoiling is probably more valuable in semi-arid or humid regions than where irrigation is macticed.

The effects of once subsoiling the land may continue for thros or more years and under onr conditions are more apfarent the serond season after the subsoiling is done than they are the first.

If subsoiling is to be practiced, we recommend doing it in the fall.

Subsoiling does not produce a uniform effect on the grains. Tnder certain conditions it may pay for wheat raised by irrigation. We have not found it profitable for oats, barley, or corm.

Crain takes longer to mature on subsoiled land. At high altitudes where the season is comparatively short it is doubtful if subsoiling for grain is adrisable.

The quantity and quality of root crops are greatly imfroved by sulssoiling the land. Subsoiling can be generally rerommended in this state for potatoes.

Tnder our conditions subsoiling has increased the amount of water needed to irrigate the land and apparently is of little ralue in conserving moisture. However, if no water rould be applied ly irrigation during the summer, the filling with moistur in the winter or spring by rainfall or irrigation of the reservoir formed br subsoiling. Would be beneficial. 


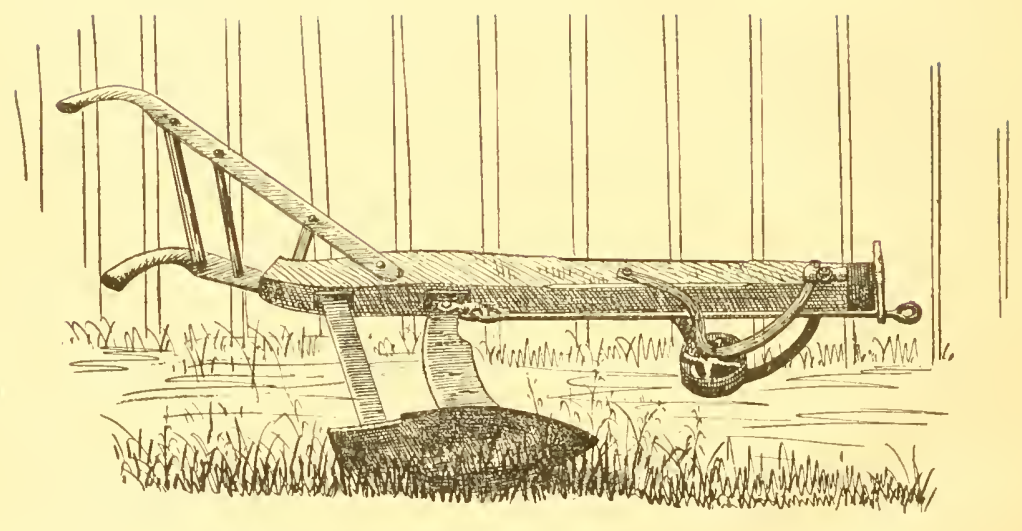









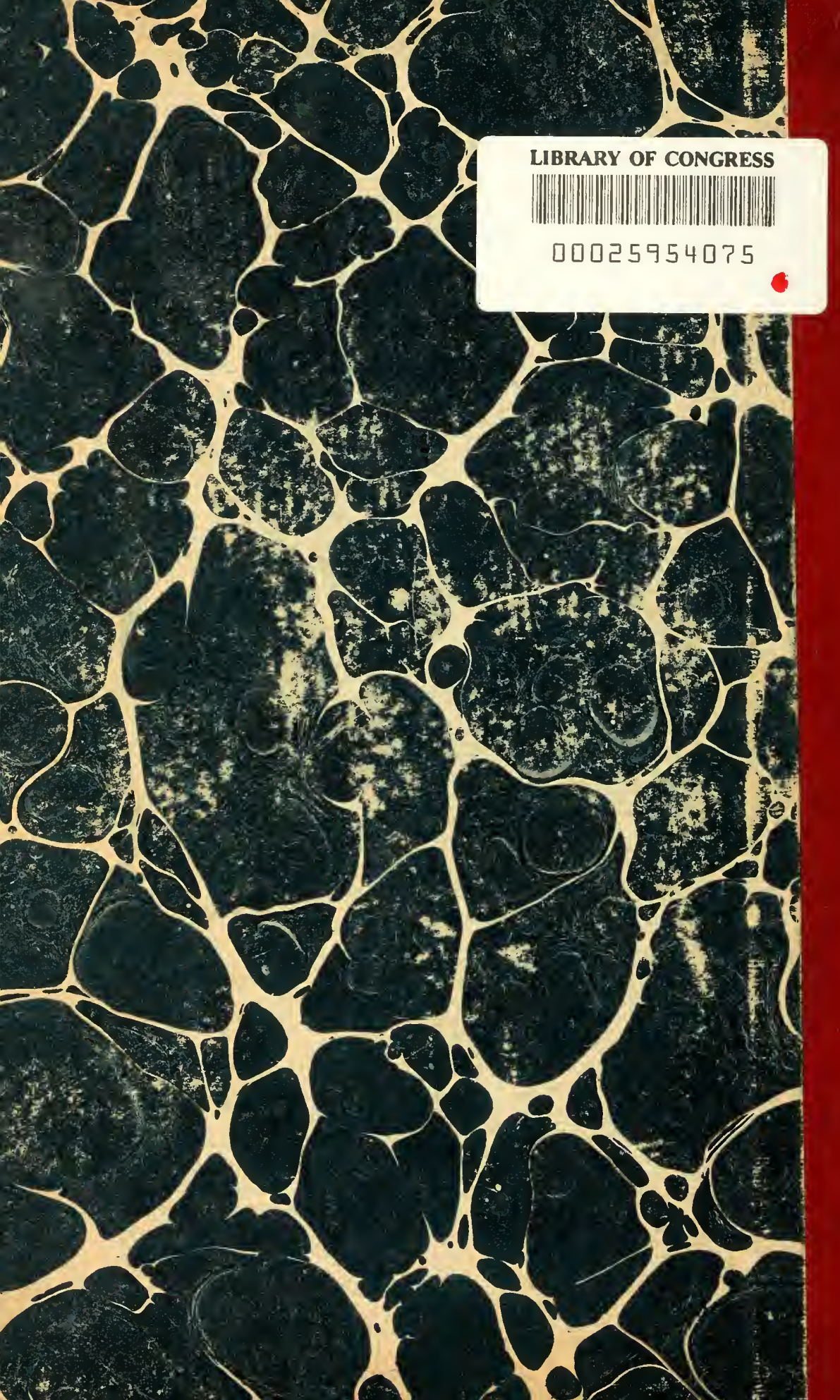

